
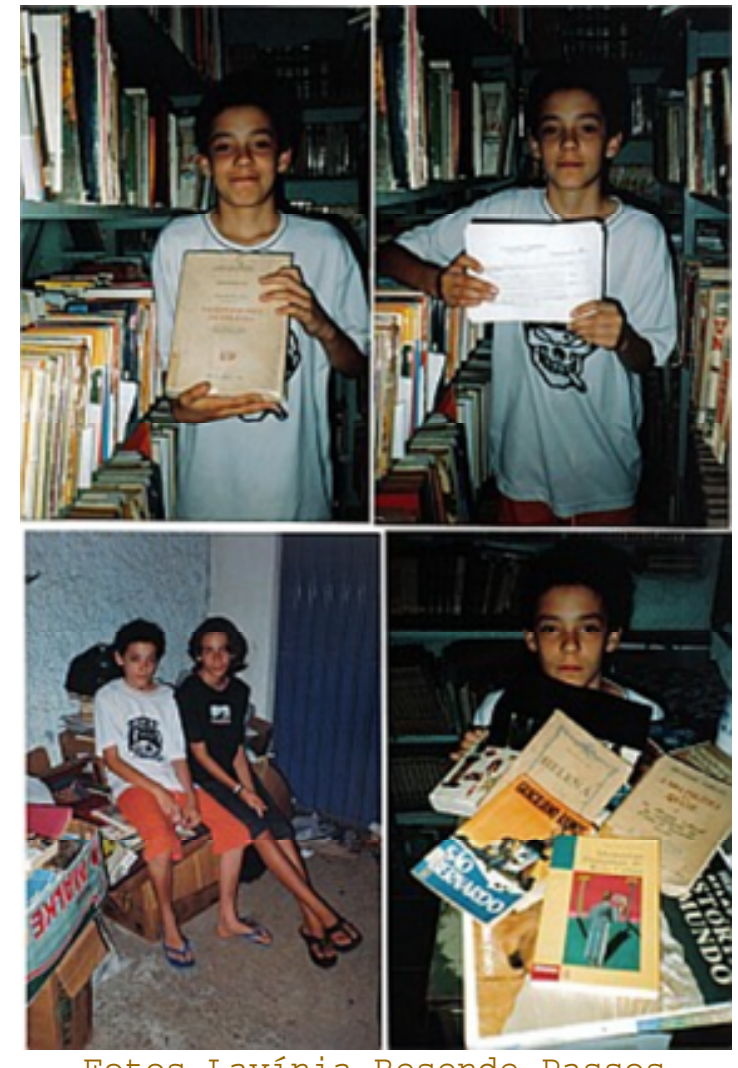

Fotos Lavínia Resende Passos

\title{
Dinâmica adolescente com olhar adulto
}

\section{Lavínia Resende Passos}

Lavínia Resende Passos é estudante de graduação na Faculdade de Letras, com Formação Complementar em Comunicaçao Social, na Universidade Federal de Minas Gerais. Há seis meses integra o grupo A tela e o texto.

No pequeno município de Santa Cruz de Minas, a iniciativa de dois irmãos tem chamado a atenção de vizinhos e moradores da região. Júlio César, de 12 anos, e samuel, de 13, tinham o hábito de trocarem livros que já haviam lido por livros ainda não lidos, e assim, desenvolverem sua leitura. Daí surgiu a idéia de terem sua própria biblioteca. Até aí, a iniciativa já devia ser parabenizada, mas eles foram além. Os dois adolescentes estudam em escola estadual, na quinta e sétima séries respectivamente, e recebem incentivos para ler de seus professores. Porém, na região onde moram não contam com 
nenhuma biblioteca, e as duas escolas existentes não disponibilizam seu acervo para a comunidade. Para que os moradores possam obter o empréstimo de um livro, é necessário ir até a biblioteca municipal de São João Del Rei, cidade vizinha. Diante disso, Júlio e Samuel decidiram criar uma biblioteca comunitária nos fundos de casa e, hoje, a Biblioteca Comunitária J. S. Laudares Gulpilhares, em oito meses de funcionamento, possui mais de 4.100 livros, todos eles doados. Eles começaram com uma doação de 200 livros, feita por uma tia. Assim que a notícia se espalhou, não faltou solidariedade. Todos os dias chegam livros de todas as áreas e materiais para conservação dos mesmos. Até mesas e cadeiras já foram doadas. Duas estantes foram compradas com dinheiro das fichas de cadastro que custa $R \$ 1,00$. Essa é a única taxa que se paga. Os livros são emprestados, podem permanecer 10 dias com o leitor e o empréstimo pode ser renovado por mais 10 dias. Cada ficha, além do titular, ainda comporta dois dependentes. Até a data da entrevista já existiam 55 fichas prontas. Entretanto, se o leitor quiser, pode apenas fazer pesquisas na biblioteca, o que é uma atividade muito desenvolvida. Com essas pessoas, que vão à biblioteca apenas para pesquisar, e com aquelas que vão acompanhando quem já é titular de uma ficha, é que Maristela, mãe de Júlio e Samuel, gasta um pouco mais de tempo: "Tento incentivá-las a levarem um livro, a mostrar como é importante ler, e a não falarem que não gostam de leitura sem antes experimentarem...". Com isso, Maristela conseguiu algumas fichas a mais no arquivo de leitura. No acervo, há um pouco de tudo: dicionários de várias línguas, inclusive Latim; enciclopédias, livros relacionados à religião, revistinhas em quadrinhos, coleções de prévestibular, livros de Matemática, Biologia e Gramáticas, entre outras matérias; e na área de Literatura há poesias e contos. Citando alguns autores, temos Gabriel Garcia Marques, Umberto Eco, Machado de Assis, Guimarães Rosa e Graciliano Ramos. Os livros listados para o vestibular de 2005 já estão disponíveis na biblioteca. Tanta solidariedade, porém, trouxe imprevistos. os jovens, mesmo contando com a ajuda dos familiares, não estão conseguindo catalogar os livros. Começaram a separar os primeiros duzentos livros por assunto, e hoje, só os romances já somam 400 livros. Primeiramente, foram anotando tudo em um caderno e depois, no computador, mas não conseguiram finalizar, uma vez que o volume que chega é maior do que o tempo disponível para atuarem na biblioteca. Tudo acontece de maneira informal: as pessoas chegam e tocam a campainha, aquele que estiver em casa e que puder atender recebe os leitores. Além da catalogação, outro imprevisto é a falta de espaço para guardar os livros. O cômodo que foi improvisado para a biblioteca não comportou o volume de livros recebidos, e até as mesas para pesquisa ficam do lado de fora. Muitos livros ainda estão encaixotados na garagem da casa esperando espaço para serem disponibilizados. Infelizmente, os garotos 
não tiveram nenhuma ajuda de um profissional da área, para ajudar na organização e na conservação. Alguns livros já chegam danificados por traças e eles não possuem instrução para arrumá-los nem recursos para pedirem ajuda a uma terceira pessoa. Quanto à Universidade Federal de São João Del Rei, apenas uma aluna da Letras lhes fez uma visita, e uma turma da Filosofia presenteou-os com convites para a inauguração e com uma placa comemorativa da mesma. O prefeito de Santa Cruz já foi convidado a conhecer a biblioteca, mas ainda não o fez. Durante a entrevista, Júlio César mostrou-se todo o tempo ativo, empolgado com o trabalho, mostrando todo o funcionamento do projeto e fazendo planos de aumentar a biblioteca. Mas ao ser questionado sobre a importância desse trabalho, Júlio não respondeu, apenas sorriu. Um sorriso tímido, um sorriso de alguém que agiu para fazer o bem, sem saber ao certo a grande dimensão de sua iniciativa. 